УДК 81 '373

DOI https://doi.org/10.26661/2414-9594-2021-1-2

\title{
АСОЦІАТИ НАЗВ ЧАСТИН ДОБИ КВАЛІТАТІВНО-ПРЕДМЕТНОЇ СЕМАНТИКИ
}

\author{
Ахмад І. М. \\ кандидат філологічних наук, \\ дочент кафедри англійської мови технічного спрямування № 1 \\ Національний технічний університет України \\ «Київський політехнічний інститут імені Ігоря Сікорського» \\ пр. Перемоги, 37, Київ, Україна \\ orcid.org/0000-0001-7673-4308 \\ innakhmad737@gmail.com \\ Семида О. В. \\ кандидат філологічних наук, \\ дочент кафедри англійської мови технічного спрямування № 1 \\ Національний технічний університет Украӥни \\ «Київський політехнічний інститут імені Ігоря Сікорського» \\ пр. Перемоги, 37, Київ, Україна \\ orcid.org/0000-0003-2042-5092 \\ osemida@gmail.com
}

Ключові слова: асочіативносемантична група, каузема, рефлексема, сема, семантична ознака.
У статті проаналізовано асоціативно-семантичну кореляцію назв частин доби та лексем 3 якісно-об'єктивним значенням. Обгрунтовано принципи включення слів у склад асоціативно-семантичних груп, виділено смислові ознаки, за допомогою яких здійснюється зв'язок між рефлексемами та кауземами. Склад і структура асоціативно-семантичних груп 3 вершинними словами «ранок», «день», «вечір» і «ніч» визначено як смислові ознаки, завдяки яким реалізується смисловий зв'язок каузем з рефлексемами. Простежується реалізація асоціативно-смислових зв'язків вивчених лексем на рівні тексту. Серед традиційно виділених лексичних парадигм асоціативно-семантична група посідає особливе місце. Вона формується як на основі причиннонаслідкових зв'язків реалій навколишнього світу, так і 3 урахуванням смислових взаємодій лексем у мові. Склад і структура цієї парадигми зумовлена смисловою структурою початкового слова. Виходячи 3 подібності номінованих реалій, рефлекси, які представляють загальний для каузем семантичний атрибут, у межах такої парадигми розподіляються по денотативних зонах. Кожен із членів АСГ може виступати як каузема стосовно інших слів формується асоціативно-семантична група другого рівня, рефлекси другого рівня виступають збудниками АСГ третього рівня тощо. Разом члени АСГ усіх рівнів, прямо або опосередковано семантично пов'язані з початковою кауземою, утворюють асоціативно-смислову структуру.

У результаті досліджень було визначено склад та архітектуру асоціативносмислової структури 3 кауземою «ранок». Він поєднує у собі рефлекси двох рівнів, які семантично пов'язані з кауземою через часові, якісно-часові та якісно-об'єктивні ознаки. Асоціативний зв'язок лексеми зумовлюється співвідношеннями явищ об'єктивного світу. Оскільки назви частин дня належать до однієї і тієї ж лексико-семантичної групи і містять однакові смислові ознаки у смисловій структурі, логічно припустити існування стандартних парадигм 3 кауземами - назвами частин доби. Формування та опис таких парадигм формує майбутнє дослідження.

У статті також визначена роль контексту у виявленні асоціативно-смислових зв'язків, подано приклади спільного функціонування кауземів та рефлексем у контексті. Перспективою дослідження є опис складу та структури типової асоціативно-семантичної групи з причинною назвою частин дня. 


\title{
DAY PARTS'ASSOCIATES OF QUALITATIVE-SUBJECT SEMANTICS
}

\author{
Akhmad I. M. \\ Ph.D. in Philology, \\ Associate Professor at the Department of English for Engineering No. 1 \\ National Technical University of Ukraine "Igor Sikorsky Kyiv Polytechnic Institute" \\ Peremohy Avenue, 37, Kyiv, Ukraine \\ orcid.org/0000-0001-7673-4308 \\ innakhmad737@gmail.com \\ Semyda O. V. \\ Ph.D. in Philology, \\ Associate Professor at the Department of English for Engineering No. 1 \\ National Technical University of Ukraine "Igor Sikorsky Kyiv Polytechnic Institute" \\ Peremohy Avenue, 37, Kyiv, Ukraine \\ orcid.org/0000-0003-2042-5092 \\ osemida@gmail.com
}

Key words: associative-semantic group, kauzeme, reflexeme, seme, semantic feature.
The article analyzes associative-semantic correlation of the names of parts of the day and lexemes with qualitative-objective meaning. The principles of the inclusion of words in the composition of associative-semantic groups are grounded, semantic features are distinguished, through which a connection is made between the reflex and the kauzemes. The composition and structure of the associative-semantic groups with the vertex words "morning", "day", "evening" and "night" are defined, and semantic features are distinguished, through which the semantic connection of the kauzem with reflexes is realized. The implementation of associative-semantic links of the studied lexemes at the level of the text is traced.

The associative-semantic group occupies a special place among traditionally distinguished lexical paradigms. It is formed both on the basis of cause-effect relations of the realities of the surrounding world, and taking into account the semantic interactions of lexemes in the language. The composition and structure of this paradigm is due to the semantic structure of the original word. Based on the similarity of the nominated realities, the reflexes that represent the semantic attribute common to the kauzemes, within the given paradigm, are distributed along the denotative zones. Each of the members of the ASG can appear as a kauzema in relation to other words. Thus, an associative-semantic group of the second level is formed, the second-level reflexes act as causative agents for the ASG of the third level and so on. Together, the members of ASGs of all levels, directly or indirectly semantically related to the original kauzema, form an associative-semantic structure. As a result of the research, the composition and architecture of the associative-semantic structure with the kauzema "morning" was determined. It combines reflexes of two levels that are semantically related to the kauzema through temporal, qualitative-temporal and qualitative-objective features. The associative connection of lexemes is conditioned by the relations of the phenomena of the objective world.

The prospect of the study is a description of the composition and structure of a typical associative-semantic group with the causal name of the day parts.
Постановка проблеми. Специфіка того чи іншого типу парадигматичних відносин у межах лексичної системи визначається або інтра-, або екстралінгвістичними факторами: на основі власне лінгвістичних взаємодій формуються, наприклад, синонімічні й антонімічні ряди, а 3 урахуванням екстралінгвістичних зв’язків номінованих явищ - гіпер-, гіпонімічні та меронімічні групи. Традиційно серед лексичних парадигм особливе місце посідає асоціативно-семантична група (АСГ), яка формується як на основі причинно-наслідкових зв’язків реалій навколишнього 
світу, так і з урахуванням семи взаємодій лексем у мові [6]. Т.В. Слива зазначає, що «кореляція членів асоціативно-семантичних груп здійснюється на рівні гіпер- і гіпосем. <..> гіперсема вихідного слова (кауземи) у семантичній структурі асоціатів (рефлексія) репрезентує диференційну семантичну ознаку, тобто виступає в ролі гіпосеми, i навпаки, родові семи рефлексії у складі кауземи є семами видовими» [7].

3 вищесказаного випливає, що склад і структура такої парадигми зумовлені перш за все семантичною структурою вихідного слова. На основі подібності номінованих реалій рефлексеми, що репрезентують спільні 3 кауземою семантичні ознаки, в межах АСГ розподіляються по денотативних зонах (наприклад, до однієї денотативної зони належать рефлексеми назв сезонів, дощ, град, сніг об'єднані семантичною ознакою «вид опадів» $[8$, с. 225]).

Мета нашого дослідження - визначення особливостей взаємодій членів АСГ з кауземами-назвами частин доби на матеріалі російської мови, виявлення компонентів значень, що визначають склад парадигми, а також розподіл їі членів за денотативними зонами.

У дефініціях частин доби експлікуються насамперед темпоральні семантичні ознаки «частин доби» i «проходження в часі» (наприклад, ранок визначається як «частина доби від закінчення ночі до початку дня, час сходу сонця, світанку» [2, с. 1407]). Однак не менш значущими є квалітативно-темпоральні та квалітативно-предметні ознаки, які відображають стан навколишнього середовища або діяльність людини в той чи інший період часу. Основними квалітативно-темпоральними характеристиками будь-якої частини доби є ступінь освітленості та температура повітря; квалітативно-предметні ознаки характеризують стан природи і людини.

Виклад основного матеріалу дослідження. Для підтвердження наявності асоціативно-семантичного зв'язку рефлексії з кауземою ми використовуємо приклади 3 художніх текстів, оскільки, згідно з А.П. Клименко, фундаментом асоціювання $\epsilon$ можливість зустрічі стимулу і асоціації в межах одного обмеженого тексту [3, с. 5], а T.М. Рогожникова зазначає, що «текст є благодатним матеріалом < ..> для формування і розвитку асоціативної структури значення слова» $[4$, с. 96].

Ранок для людини - час пробудження від нічного сну, початок дня, що зумовлює наявність серед асоціатів лексеми ранок таких слів і поєднань, як встати/вставати, кінець сну, підйом, пробудження, початок дня і под. [5; 9]. На мовному рівні в семантиці кауземи виявляється периферична семантична ознака «активізація життєдіяльності». Рефлексеми, для яких така семантична ознака є ядерною (пробу- дження, підйом та ін.), утворюють окрему денотативну зону у складі відповідної АСГ.

День традиційно вважається періодом найбільшої активності. На мовному рівні у семантичній структурі лексеми день квалітативно-предметна ознака «стан людини» реалізується семою «найвищий ступінь активності»: Было то время, когда утомленные дневными трудами и заботами парубки и девушки шумно собирались в кружок, в блеске чистого вечера... /А. Чехов/; Я не болел. Просто работа, днем и ночью /Б. Акунін/; Но вот однажды днем присела Пелагея за работу /М. Зощенко/; О, как пронзительны и дики, Как ненавистны для меня Сей шум, движенье, говор, крики Младого, пламенного дня!.. /Ф. Тютчев/; Здесь ночью нега и покой, А днем и шум и пированье /О. Пушкін/. Не варто забувати, що в ранковий і денний час активізується життєдіяльність не тільки людини, але і більшості живих істот, отже, значення «активізація життєдіяльності» може репрезентувати у складі каузем як семантична ознака «стан людини», так і ознака «стан природи». Будильник мирно тикал на тумбочке, показывая десять утра - время, недопустимое для пробуждения /П. Астахов, Т. Устинова/; День - сей блистательный покров, - День, земнородных оживленье /Ф. Тютчев/ (будильник - атрибут повсякденного життя людини, земноводні - представники живої природи).

Денна діяльність закінчується до вечора, який своєю чергою переходить у ніч - час сну. Згідно 3 даними асоціативних словників, 3 вечором зазвичай асоціюються тиша і спокій [5, с. 87]. Відповідно, лексеми, які експлікують ознаки «тиша» $\mathrm{i}$ «спокій» або містять їх в якості ядерних, можуть бути включені до складу АСГ вечір (у семантичній структурі кауземи ці ознаки представлені на периферії) і віднесені до денотативної зони позначень стану навколишнього середовища. Зв'язок рефлексії $з$ кауземою простежується в таких контекстах: Помню - долгий зимний вечер, Полумрак и тишина /I. Бунін/; Как я любил твои отзывы, Глухие звуки, безднь глас, И тишину в вечерний час, И своенравные порывы /Ф. Тютчев/.

Ніч - період спокою, відпочинку: в нічний час життя затихає, діяльність людини припиняється. Такий екстралінгвальний факт знаходить відображення і на мовному рівні: у семантичній структурі лексеми ніч квалітативно-предметні ознаки «стан природи» і «стан людини» представлені семами «спокій» і «відпочинок». Рефлексеми, що репрезентують такі значення, розподіляються за двома денотативними зонами: позначення стану природи і позначення стану людини.

Стан природи у нічний період характеризують перш за все лексеми тиша і спокій (Тишина холодной ночи Занимает дух /А. Фет/; Ночь морозная, 
тих покой перекрестка, Я один у окошка - ни врага, ни друга не жду/С. Есенин/), а також синоніми дрімота («|| Трад.-поэт. Покой, оцепенение, неподвижность (о природе)» [2, с. 284]) і сон («\| О состоянии полного покоя и тишины в природе (обычно ночью)» [2, с. 1234]): Тиха украинская ночь. Прозрачно небо. Звезды блешут. Своей дремоты превозмочь не хочет воздух /О. Пушкін/.

Для деяких людей через різні причини (особливості організму, стан здоров'я або спосіб життя) ніч (так само як і вечір, про що йшлося вище) є періодом активності. Лексеми, які називають таких людей, включені до складу АСГ 3 кауземою ніч, де вони утворюють окрему денотативну зону. Це такі рефлексеми, як сова - «3. Психол. Організація психіки людини, період активності якої припадає на нічний час; людина такого типу» і нічник - «1. Людина, що виконує будьякий вид роботи в нічний час »[2, с. 658]: Tux, хто встає рано і встигає зранку багато зробити, називають «жайворонками». А ось люди-«сови» діяльні все більше по ночах, а з ранку ходять, як сонні мухи /3 газети/. На підставі викладеного, так само, як і в описаному вище випадку, можна говорити про можливість виділення семи «активізація життєдіяльності» в межах ознаки «стан людини» у семантичній структурі слова ніч. Будьякий часовий період нашого життя заповнений певними подіями. Так, для ранку традиційними $\epsilon$ сніданок - «Час ранкового прийняття їжі; ранкова їжа або їжа, що передує обіду» [2, с. 315] і утреня (утреня) - «Церковна служба християн, що здійснюється рано вранці, до обідні» [2, с. 354]. Виділені лексеми утворюють денотативну зону, корелюючи 3 кауземою за допомогою семантичної ознаки «час здійснення»: Тем более, никому не удалось толком поспать и проснуться, я даже не помню, был ли в то утро завтрак/М. Петросян/.

У словниках асоціативних норм серед асоціатів слова «ранок» представлена лексема зарядка («2. Сукупність оздоровчих фізичних вправ» [2, с. 343]). Така лексема амбівалентна, до складу АСГ ранок вона, скоріше, повинна входити в склад розчленованого найменування ранкова зарядка, але оскільки такий комплекс вправ виконується найчастіше вранці (у Вікіпедії знаходимо таке визначення: «Зарядка - комплекс фізичних вправ, що виконуються, як правило, вранці з метою розминки м'язів і суглобів»), можна стверджувати, що сема «ранок» представлена у семантичній структурі рефлексеми: вона репрезентує периферійну семантичну ознаку «час проведення». Отже, слово «зарядка» може бути включено до складу АСГ і без лексичного конкретизатора, що підтверджується такими прикладами: $Я$ с сорока лет, когда впервые почувствовал, что молодость уходит, взял себе за правило каждое утро делать часовую зарядку, и чтоб непременно сорок отжиманий Б. Акунін/.

У багатьох російськомовних респондентів, які брали участь в асоціативних експериментах, день асоціюється насамперед 3 обідом (обід «1. Основний прийом їжі, їжа (зазвичай у середині дня» [2, с. 664]). До групи слів, які резпрезентують прийом їжі в денний час, належить також слово «полдник», яке визначається як «легка їжа між обідом і вечерею, час такого прийому їжі» [2, с. 898]. До денотативної зоні «денних» подій слід віднести і рефлексії обідня - «1. Церк. Християнське богослужіння, що здійснюється вранці або в першій половині дня; літургія»[2, с. 664]. Усі згадані лексеми асоціюються зі словом «день» (про що свідчать дані асоціативних словників [5; 9]), а також семантично пов'язані з ним за допомогою значення «час проведення/здійснення».

Слід зазначити, що слово «обідня» має поліасоціативний характер, про що свідчить його дефініція, у якій експліковані диференціальні семи «ранок» $\mathrm{i}$ «день». Як бачимо, це слово може бути включене до складу двох АСГ (з кауземами ранок і день): B самыий Петров день, поутру, после обедни, когда все у нас были в полном сборе, стали приводить продажных ломадей/Ф. Достоевский/.

Висновки. Вивчення семантичної близькості асоціативно пов'язаних слів є досить актуальним напрямом сучасної лінгвістики. У межах асоціативної семантики вивчаються принципи класифікації асоціативно пов'язаних мовних одиниць, їх типологія, смислові відносини між словом-стимулом і його асоціатами. У перспективі планується опис складу і структури типової асоціативно-семантичної групи 3 кауземою - назвою частини доби.

\section{ЛITЕРАТУРА}

1. Ахмад I.М. Квалитативно-предметные рефлексемы названий частей суток. Система i структура східнослов'янських мов : збірник наукових праць / редкол.: Ю.В. Кравцова. Нац. пед. ун-т імені М.П. Драгоманова. Київ : Вид-во НПУ ім. М.П. Драгоманова, 2017. Вип. 12. С. 310.

2. Ахмад I.M. Ассоциативно-семантические корреляции лексем утро. Наукові пращі Кам'янець-Подільського національного університету імені Івана Огієнка. Філологічні науки. Випуск 44. Кам'янець-Подільський : Аксіома, 2017. С. 378.

3. Ахмад І.М. Ассоциативно-семантические объединения слов: их специфика и сфера исследования. Духоўная спадчына Усходняга Палесся : зборнік навуковых артыкулаў / рэдкал.: А.М. Воінава (гал. рэд.) і інш. М-ва адукацыі Рэспублікі Беларусь, Гомельскі дзярж. ун-т імя Ф. Скарыны. Гомель : ГДУ імя Ф. Скарыны, 2018. С. 274. 
4. Балли Ш. Общая лингвистика и вопросы французского языка. Москва : Иностр. л-ра, 1955. С. 416.

5. Большой толковый словарь русского языка / С.А. Кузнецов и др. Санкт-Петербург : Норинт, 2003. C. 1536.

6. Клименко А.П. Проблема лексической системности в психолингвистическом освещении : автореф. дис. на соискание уч. степени доктора филол. наук : спец. : 10.02 .19 «Теория языка». Минск, 1980. С. 41.

7. Рогожникова Т.М. Ассоциативная структура значения слова и процесс понимания текста. Психолингвистические проблемы семантики. Калининский гос. ун-т, Тверь. 1990. С. 96-100.

8. Русский ассоциативный словарь. В 2 т. Т. 1. От стимула к реакции / Ю.Н. Караулов и др. Москва : ООО «Издательство Астрель» : ООО «Издательство АСТ», 2002. С. 784.

9. Слива Т.В. Ассоциативно-семантическая группа как форма парадигматической организации лексики (на материале названий сезонов в русском языке). Киев : Изд-во НПУ имени М.П. Драгоманова, 2011. С. 272.

10. Слива Т.В. Ассоциативно-семантическая группа: к вопросу о дефиниции парадигмы. Вестник Самарского университета. История, педагогика, филология. № 3.2. 2016. С. 101-107.

11. Словарь ассоциативных норм русского языка / А.А. Леонтьев и др. Москва : Изд-во Моск. ун-та, 1977. C. 192.

\section{REFERENCES}

1. Akhmad, I.M. (2017). Kvalitativno-predmetnye refleksemy nazvaniy chastey sutok [Qualitative-subject reflexes of the names of the parts of the day] Systema i struktura skhidnoslov'jansjkykh mov: zbirnyk naukovykh prac / redkol.: Yu.V. Kravtsova. Nats. ped. un-t imeni M.P. Dragomanova. Kyiv: Vid-vo NPU im. M.P. Dragomanova, Vip. 12. P. 310.

2. Akhmad, I.M. (2017). Assotsiativno-semanticheskie korrelyatsii leksem utro [Associative-semantic correlations of lexemes morning]. Naukovi praci Kam'janec-Podiljsjkogho nacionaljnogho universytetu imeni Ivana Oghijenka. Filologhichni nauky. Vypusk 44. Kamianets-Podilskyi. P. 378.

3. Akhmad, I.M. (2018). Assotsiativno-semanticheskie ob'edineniya slov: ikh spetsifika i sfera issledovaniya [Associative-semantic associations of words: their specificity of research]. Dukhoy̆naja spadchyna Uskhodnjagha Palessja: zbornik navukovykh artykulay̆ / redkal.: A.M. Voinava (ghal. red.) i insh. M-va adukacyi Respubliki Belarusj, Gomel, P. 274.

4. Balli, Sh. (1955). Obshchaya lingvistika $i$ voprosy frantsuzskogo yazyka [General linguistics and questions of the French language]. Moscow: Inostr. 1-ra [in Russian].

5. Bol'shoy tolkovyy slovar' russkogo yazyka (2003). [Comprehensive explanatory dictionary of the Russian language]. S.A. Kuznetsov i dr. Sankt-Peterburg: Norint [in Russian].

6. Klimenko, A.P. (1980). Problema leksicheskoy sistemnosti v psikholingvisticheskom osveshchenii [The problem of lexical consistency in psycholinguistic coverage] (PhD Thesis), Minsk [in Russian].

7. Rogozhnikova, T.M. (1990). Assotsiativnaya struktura znacheniya slova $i$ protsess ponimaniya teksta [The associative structure of the meaning of a word and the process of understanding the text]. Psikholingvisticheskie problemy semantiki. Kalininskiy gos. un-t, Tver [in Russian].

\begin{tabular}{l} 
8. Russkiy assotsiativnyy slovar' (2002). V 2 t. T. 1. Ot stimula k reaktsii [Russian associative \\
\hline
\end{tabular} dictionary] Yu.N. Karaulov i dr. Moskva: OOO “Izdatel'stvo Astrel”" [in Russian].

9. Sliva, T.V. (2011). Assotsiativno-semanticheskaya gruppa kak forma paradigmaticheskoy organizatsii leksiki (na materiale nazvaniy sezonov v russkom yazyke) [Associative-semantic group as a form of paradigmatic vocabulary organization]. Kyiv: Izd-vo NPU M.P. Dragomanova. P. 272.

10. Sliva, T.V. (2016). Assotsiativno-semanticheskaya gruppa: $k$ voprosu o definitsii paradigmy [Associativesemantic group: on the question of the definition of a paradigm]. Vestnik Samarskogo universiteta. Istoriya, pedagogika, filologiya. No. 3.2. Samara, pp. 101-107.

11. Slovar'assotsiativnykh norm russkogo yazyka (1977). [Dictionary of associative norms of the Russian language]. A.A. Leont'ev i dr. Moskva: Izd-vo Moscow un-t [in Russian]. 